\title{
LOGICAL CULTURE OF ANCIENT RUS
}

\author{
(C) Evgeny P. Agapov, Lyudmila P. Pendyurina \\ Rostov State University of Economics, Don State Technical University, \\ Rostov-on-Don, Russian Federation \\ march10@mail.ru, prinpet@mail.ru
}

The article is devoted to the formation of logic in Russia, which began in the $18^{\text {th }}$ century. However, its prerequisites go into much deeper layers of Russian culture. The logical culture of any society is a characteristic set of stereotypes of thinking, which is manifested in the methods of argumentation, as well as in the ability to evaluate inferences, develop hypotheses, systematize objects, etc. The first logical and philosophical treatise in Ancient Rus is considered to be the "Anthology of Svyatoslav," the logical part of which contained a presentation of the Aristotelian treatise "Categories," as well as a commentary on it, written in the $3^{\text {rd }}$ century by the Syrian logician Porphyry. More extensive logical material could be drawn from the translations and renditions of "Dialectics," written in the $8^{\text {th }}$ century by Byzantine theologian John of Damascus. The Aristotelian categories were considered in them, as well as judgment and categorical syllogism. The emergence of logic in Russia was associated not only with its internal objective laws, but also with needs for the development of those areas of theoretical and practical activity in which the important role was assigned to the validity and persuasiveness of reasoning. Mathematics and philosophy were the most important among the areas of theoretical activity. Governance of community and veche was the most important among the areas of practical activity. The development of logical culture, which began in Ancient Rus in the $11^{\text {th }}$ century, in the $18^{\text {th }}$ century led to the formation of logic in Russia. But it took decades for logic in Russia to become an independent science.

Key words: culture, logical culture, ancient Russian culture, logic as a science, logic prerequisites, doctrine of inference.

\section{[Е.П. Агапов, Л.П. Пендюрина Логическая культура Древней Руси]}

Статья посвящена становлению логики в России, которое началось в 18 в. Однако её предпосылки уходят в значительно более глубокие пласты отечественной культуры. Логическая культура любого общества представляет собой характерную для него совокупность стереотипов мышления, которая проявляется в способах аргументации, а также в умении оценивать умозаключения, разрабатывать гипотезы, систематизировать объекты и т. д. Первым логикофрилософским трактатом в Древней Руси считается «Изборник Святослава», логическая часть которого содержала изложение аристотелевского трактата «Категории», а также комментария к нему, написанного в 3 в. сирийским логиком Порфирием. Более обширный логический материал можно было почерпнуть из переводов и переложений «Диалектики», написанной в 8 в. византийским богословом Иоанном Дамаскином. В ней рассматривались аристотелевские категории, а также суждение и категорический силлогизм. Возникновение логики в России было связано не только с её внутренними закономерностями, но и с потребностями развития тех областей теоретической и практической деятельности, в которых важная роль отводилась обоснованности и убедительности рассуждений. Из областей теоретической деятельности важнейшими были математика и философия, а из областей практической деятельности - общинно-вечевое правление. Развитие логической культуры, начавшееся в Древней Руси в 11 в., привело в 18 в. к становлению логики в России. Но ещё потребовалось несколько десятилетий, чтобы логика в России превратилась в самостоятельную науку.

Ключевые слова: культура, логическая культура, древнерусская культура, логика как наука, предпосылки логики, учение об умозаключениях.

Evgeny P. Agapov - Ph.D. (Advanced Doctorate) in Philosophy, Professor, Rostov State University of Economics, Rostov-on-Don, Russian Federation.

Lyudmila P. Pendyurina - Ph.D. (Advanced Doctorate) in Philosophy, Associate Professor, Don State Technical University, Rostov-on-Don, Russian Federation. 
Агапов Евгений Петрович - доктор фрилософрских наук, профрессор, Ростовский государственный экономический университет, Ростов-на-Дону, Российская Федерация.

Пендюрина Людмила Петровна - доктор философрских наук, доцент, Донской государственный технический университет, Ростов-на-Дону, Российская Федерация.

Logic as a science that arose in the $4^{\text {th }}$ century BC in ancient Greece, in Russia appeared only in the $18^{\text {th }}$ century. The first national essay on logic is considered to be "Letters to the German princess about various physical and philosophical substances," written by the outstanding scientist Leonhard Euler [5, p. 407]. In logic, the method of visualizing the volumes of concepts in the form of circles is associated with his name. This method was improved in the $19^{\text {th }}$ century by the English scientist John Wenn. In the $18^{\text {th }}$ century, logic was also taught in the logical academies and seminaries that trained clergy and church scholars. At the Kiev Theological Academy, logic courses were taught in the spirit of Peter of Spain and Christian Wolff, and at the Slavic-Greek-Latin Academy, later transformed into the Moscow Theological Academy, as one of the seven free arts that fell into trivium (grammar, logic, rhetoric) and quadrivium (arithmetic, geometry, music, astronomy). Finally, the St. Petersburg Academy of Sciences and Moscow University became secular centers of Russian science [7 p. 418]. Thus, we can assert that the formation of logic in Russia began in the $18^{\text {th }}$ century. However, its prerequisites go into much deeper layers of domestic culture, which can be defined as Old Russian culture. The purpose of the article is to identify historical prerequisites in this culture, on the basis of which the formation of logic as a science began in Russia in the $18^{\text {th }}$ century.

The title of the article reflects three concepts, the meanings of which we must clarify. They are the concepts of culture, logical culture and ancient Russian culture. Following an activity approach to culture, we will consider it as everything that is created by people, and does not exist in nature. Culture is a system of elements that are both interconnected and relatively separate.

It follows from our understanding of culture that its fundamental characteristic is integrity [10, p. 157]. Therefore, we can raise the question of how the previous development of culture led to the formation of logic as a science in Russia in the $18^{\text {th }}$ century. If the formation of logic in Russia began only in the $18^{\text {th }}$ century, then what elements of the previous culture led to this formation? We believe that the development of the logical culture of Ancient Rus led to it.

Considered as an element of the general culture of the individual, logical culture is his existing skills in operating concepts, judgments, conclusions and other forms of thinking [1, p. 16]. These skills are not given to a person from birth, but are formed as he masters his native language, which is not only a means of communication, but also a means of expressing knowledge. Logical culture can be an element not only of the general culture of the individual, but also of the culture of certain historical eras, specific societies, nationalities, etc. Therefore, we can speak, for example, about the logical culture of Ancient Greece or about the logical culture of Ancient Rus. The logical culture of any society is a characteristic set of stereotypes of thinking, which is manifested in the methods of argumentation, as well as in the ability to evaluate conclusions, develop hypotheses, systematize objects, etc. People are brought up not only in a certain political, moral, aesthetic, etc., environment that forms their views and beliefs, but also in a certain logical environment, under the influence of which their logical culture develops [9, p. 116].

Having clarified the meanings of the concepts of culture and logical culture, we turn to the concept of ancient Russian culture (or the culture of Ancient Rus). This concept is used in two meanings, which differ in the time frame of the existence of ancient Russian culture. In the first sense, it means the culture of Russia from the moment of the Old Russian state formation in the $9^{\text {th }}$ century to the Mongol-Tatar invasion, which occurred in 
1237 and lasted for three years. This meaning, reflected in most scientific and educational literature, is the main one. In the second sense, the concept of ancient Russian culture means the totality of material and spiritual culture, which had been developed by the $17^{\text {th }}$ century, when the final formation of the Russian nation, statehood and the Orthodox Church took place [2, p. 255]. We will use this concept in the second, broad sense, in which it covers not only the culture of Ancient, but also Medieval Rus.

The Old Russian state was characterized by a high level of cultural development associated with its geographical location, thanks to which it could use the cultural achievements of its neighbours, taking all the best from them and forming its own traditions. Through Byzantium, whose traditions fertilized the culture of Ancient Rus, based on a pagan worldview, it joined the rich heritage of antiquity. This legacy included mathematics, philosophy and other elements of culture.

The first logical and philosophical treatise in Ancient Rus is considered to be the "Anthology of Svyatoslav," compiled in 1073 [11, p. 130]. Intended for Grand Prince Sviatoslav II Iaroslavich, it included 383 articles based on the works of the Church Fathers and the Holy Scriptures. The "Anthology of Svyatoslav" was a composite work, the logical part of which contained a presentation of the Aristotelian treatise "Categories," as well as a commentary on it, written in the $3^{\text {rd }}$ century by the Syrian logician Porphyry. Until the middle of the $12^{\text {th }}$ century the main manuals on logic included the works of the Roman philosopher Boethius, as well as the treatise of Porphyry, known as the "Introduction to the "Categories" of Aristotle." According to this treatise, the inhabitants of Ancient Rus could get acquainted with some of the logical ideas of Aristotle, which were adapted by medieval scholastics to the needs of Christianity [3, p. 98]. More extensive logical material could be drawn from the translations and renditions of "Dialectics," written in the $8^{\text {th }}$ century by Byzantine theologian John of Damascus, who was the first to try to present the Aristotelian doctrine in the service of the church. The main provisions of the Aristotelian logic were briefly outlined by him in the essay "The Source of Knowledge," and in the treatise "Dialectics" he also devoted several chapters to it. The Aristotelian categories were considered in them, as well as judgment and categorical syllogism [13, p. 212]. Separate fragments of "Dialectics" were placed into the "Anthology of Svyatoslav," and its full translation into Russian appeared no later than the $13^{\text {th }}$ century [14, p. 357]. Acquaintance with categorical syllogism, which is a kind of conclusion, is an important stage in the development of the logical culture of Ancient Rus.

Liberation from the Mongol-Tatar Yoke led to the rise of the self-consciousness of the Russian people, which was reflected in the reformation movements of the $14^{\text {th }}-16^{\text {th }}$ centuries. In the process of liberation from the dogmatic shackles of Christianity, there was a need to consider true not what is groundlessly proclaimed, but what is really proved. In turn, it caused interest in serious logical studies, the example of which is the "Logic of Aviasaf," which is a translation into Old Russian of logical fragments from the works of a Muslim theologian, jurist and philosopher al-Ghazali [3, p. 98].

At the end of the $15^{\text {th }}$ century the system of logical terms appeared in the Old Russian language, which was a reworking of the work of the Jewish philosopher Maimonides, who in the Middle Ages was considered the largest authority among rabbis. Maimonides, who was a follower of Aristotle in Jewish philosophy and logic, owns two works - "Logic" and "The Guide for the Perplexed" [15, p. 110].

The Old Russian treatise on logical terms is known as "The Book called Logic." It is a manual on the logic of Maimonides, which was created under the influence of "Logic of Aviasaf," and also contains borrowings from al-Ghazali's Metaphysics. If "Logic of Aviasaf" concerns the general provisions of logical science, then "The Book called Logic" focuses on the interpretation of logical terms. The total number of terms contained in two books is 150 concepts. The texts of al-Ghazali and Maimonides, translated into Old Russian, testify 
to the great influence that aristotelianism had on Russian philosophy of the $15^{\text {th- }} 16^{\text {th }}$ centuries [8, p. 269].

The emergence of logic in Russia was associated not only with its internal objective laws, but also with the needs for the development of those areas of theoretical and practical activity in which the important role was assigned to the validity and persuasiveness of reasoning. Mathematics and philosophy were the most important among the areas of theoretical activity. Governance of community and veche was the most important among the areas of practical activity.

In Russian literature, the first mathematical information can be found in the $11^{\text {th }}$ century in "Russkaya Pravda," which is a legal code of Ancient Rus. This information relates to the calculation of debts, fines, interest, etc. In 1136, the Novgorod monk Kirik wrote an essay that contained a detailed calculation of the date of the world creation [3, $p$. 64]. In the $13^{\text {th }}$ century in connection with the Mongol-Tatar invasion, Russian principalities were isolated from Western culture, and communication with Byzantium was difficult. Like all other books that came from the West, writings on mathematics were banned by the church [16, p. 22].

In the $16^{\text {th }}-17^{\text {th }}$ centuries, the strengthening of the state was noted, the result of which was a change in attitude to mathematics. The needs of the development of the economy, as well as the construction of the army, required an increase in the level of education in general and mathematical in particular. Foreign specialists began to be invited to Moscow, and Western manuals on mathematics and application-oriented sciences were translated into Russian. In 1725, the St. Petersburg Academy of Sciences was established, to which the largest European mathematicians were invited - Leonhard Euler and Daniel Bernoulli.

As in Byzantium and in the West, various thought traditions coexisted and competed in Ancient Rus. The earliest of them was the Cyrillo-Methodian tradition, according to which philosophy is aimed at knowing the nature of the world and God. Both rationalized theology and worldly wisdom were identified with it, which complemented each other, allowing a person to make a conscious moral choice that brings him closer to God.

The interpretation of philosophy as the knowledge of invisible (beatific) things and human, earthly things that are accessible to feelings dates back to the "Dialectic" of John of Damascus, translated into Russian. It was also understood as love of wisdom, which meant the same as love of God. Philosophy, coinciding essentially with theology, set worldview prerequisites for knowing the material world, and also formulated the norms of the Right Livelihood. If Cyrillo-Methodian understanding of philosophy was reduced to the knowledge of being, revealing all spheres of the world, then according to John of Damascus it was not so much in understanding the secrets of being, but in understanding the provisions of Christian doctrine that were obtained through revelation. In the tradition coming from it, a theologically educated person was considered a philosopher who was supposed to know grammar, rhetoric, mathematics, logic and philosophy itself. Thus, philosophy in this tradition was assigned a supporting role, which was to protect and explain theological provisions [4, p. 10].

In all areas of practice that relate to communication between people, their ability to reason correctly, which aims to convince others of the correctness of their point of view, plays an important role. However, it is of particular importance in those policy areas that are governed by democratic governance. If we turn to the history of Ancient Rus, then we can find such principles in Novgorod and Pskov, the state structure of which is characterized as Old Russian democracy.

Back in ancient times, governance arose in Novgorod, which is called community and veche by experts. In the $12^{\text {th }}$ century veche became free from princely power, having received the right to elect a posadnik, a tysiatskii and even a bishop, that is, the right to appoint the entire administration of the city. The Novgorod Republic lasted until 1478, 
when it was conquered by Ivan III and became part of the Russian state. In the $13^{\text {th }}$ century the heyday of veche organization was also observed in Pskov, which until the $14^{\text {th }}$ century was part of the Novgorod Republic, using wide autonomy, and then became completely independent until it became part of the Russian state.

Veche discussed the main problems of home and foreign policy, which included the approval of standing orders and laws, the issuance of letters of grant, the resolution of issues of invitation and expulsion of the prince, as well as the election of a posadnik, a tysiatskii and a bishop. The votes of the participants in the meeting were not counted, and the decision was determined by the strength of their cry. The democratic structure of the Novgorod Republic was later used by the Cossack communities of Russia, who built their state entities in its image and likeness [6, pp. 27-28].

The development of logical culture, which began in Ancient Rus in the $11^{\text {th }}$ century, in the $18^{\text {th }}$ century led to the formation of logic in Russia. It was associated not only with internal laws, but also with the needs for the development of mathematics, philosophy and community and veche government. In the $18^{\text {th }}$ century works that reveal certain aspects of the doctrine of inference began to appear. Leonhard Euler, who was a mathematician who understands the importance of logic for science, gave a detailed account of Aristotelian syllogistics, as well as the method he developed to visualize the relations between concepts [12, pp. 220-241]. However, after him for fifty years any works on logic hadn 't been written until at the beginning of the $19^{\text {th }}$ century universities were opened in Tartu, Kazan and Kharkiv, the appearance of which stimulated the development of philosophical research in general and logical in particular. But it took decades for logic in Russia to become an independent science.

\section{Лumepamypa}

1. Агапов Е.П. Логика. М. 2015. 160 с.

2. Безрукова В.С. Основы духовной культуры (энциклопедический словарь педагога). Екатеринбург. 2000. 937 с.

3. Естественнонаучные представления Древней Руси: сборник статей. М. 1978. $176 \mathrm{c}$.

4. История русской фрилософрии / под ред. М. А. Маслина. М. 2001. 639 с.

5. Логика в России // Новая философрккая энциклопедия. В 4 т. Т. 1 / под ред. В.С. Стёпина. М. 2010. С. 407-414.

6. Мазурин А.H. Демократическое управление в Новгородской республике // Фундаментальные и прикладные исследования: проблемы и результаты. 2015. № 21. С. 25-29.

7. Маковельский А.О. История логики. М. 2004. 480 с.

8. Мильков В.В. Переводные фрилософрские сочинения в русской книжности конца XV - середины XVI веков: еврейские и арабские влияния // Историкофилософрский ежегодник. 2016. С. 269-295.

9. Свинцов В.И. Логическая культура личности и общества // Общественные науки и современность. 1993. № 4. С. 114-124.

10. Сорина Г.В., Меськов В.С. Вперёд к логике: использован ли в полной мере потенциал логики при анализе и моделировании рассуждений? // РАЦИО.ru. 2009. № 2. С. 152-196.

11. Шапчиц П.А. Очерк истории логики и логической терминологии Древней Руси // Актуальные проблемы русской философии и культуры. СПб. 2007. С. 130-142.

12. Эйлер Л. Письма к немецкой принцессе о разных фризических и фрилософских материях. СПб. 2002. 719 с. 
13. Кондаков Н.И. Логический словарь-справочник. 2-е, испр. и доп. изд. М. 1975. $717 \mathrm{c}$.

14. Гаврюшин Н.К. Митрополит Даниил - редактор «Диалектики» // Труды Отдела древнерусской литературы. Т. XLI. Л. 1988. С. 357-363.

15. Стяжкин Н.И. Формирование математической логики. М. 1967.504 с.

16. Гнеденко Б.В. Очерки по истории математики в России. М.-Л. 1946. 247 с.

\section{References}

1. Agapov E.P. Logika [Logic]. Moscow. 2015. 160 p. (in Russian).

2. Bezrukova V.S. Osnovy dukhovnoi kultury (entsiklopedicheskii slovar pedagoga) [Fundamentals of Spiritual Culture (teacher's encyclopedic dictionary)]. Yekaterinburg. 2000. 937 p. (in Russian).

3. Estestvennonauchnye predstavleniia Drevnei Rusi: sbornik statei [Natural science representations of Ancient Rus: Collection of articles]. Moscow. 1978. 176 p. (in Russian).

4. Istoriia russkoi filosofii pod red. M.A. Maslina [History of Russian Philosophy edited by M.A. Maslin]. Moscow. 2001. 639 p. (in Russian).

5. Logika $v$ Rossii. Novaia filosofskaia entsiklopediia [Logic in Russia. New philosophical encyclopedia]. In 4 volumes. V. 1 edited by V.S. Stepin. Moscow. 2010. pp. 407-414 (in Russian).

6. Mazurin A.N. Demokraticheskoe upravlenie $v$ Novgorodskoi respublike. Fundamentalnye i prikladnye issledovaniia: problemy i rezultaty [Democratic governance in the Novgorod Republic. Fundamental and applied research: problems and results]. 2015. No. 21. pp. 25-29 (in Russian).

7. Makovelsky A.O. Istoriia logiki [History of logic]. Moscow. 2004. 480 p. (in Russian).

8. Milkov V.V. Perevodnye filosofskie sochineniia $v$ russkoi knizhnosti kontsa XV serediny XVI vekov: evreiskie i arabskie vliianiia. Istoriko-filosofskii ezhegodnik [Translated philosophical works in the Russian bookishness of the late $15^{\text {th }}$ - mid$16^{\text {th }}$ centuries: Jewish and Arab influences. Historical and Philosophical Yearbook]. 2016. pp. 269-295 (in Russian).

9. Svintsov V.I. Logicheskaia kultura lichnosti i obshchestva. Obshchestvennye nauki i sovremennost [The logical culture of the individual and society. Social sciences and modernity]. 1993. No. 4. pp. 114-124 (in Russian).

10. Sorina G.V., Meskov V.S. Vpered k logike: ispolzovan li v polnoi mere potentsial logiki pri analize i modelirovanii rassuzhdenii? [Forward to logic: has the full potential of logic been used in the analysis and modeling of reasoning?] RACIO.ru. 2009. No. 2. pp. 152-196.

11. Shapchits P.A. Ocherk istorii logiki i logicheskoi terminologii Drevnei Rusi. Aktualnye problemy russkoi filosofii i kultury [Essay on the history of logic and logical terminology of Ancient Rus. Actual problems of Russian philosophy and culture]. Saint Petersburg. 2007. pp. 130-142 (in Russian).

12. Euler L. Pisma k nemetskoi printsesse o raznykh fizicheskikh i filosofskikh materiiakh [Letters to the German princess about different physical and philosophical substances]. Saint Petersburg. 2002. 719 p. (in Russian).

13. Kondakov N.I. Logicheskii slovar-spravochnik [Logical dictionary]. The $2^{\text {nd }}$ revised and enlarged edition. Moscow. 1975. 717 p. (in Russian).

14. Gavryushin N.K. Mitropolit Daniil - redaktor "Dialektiki". Trudy Otdela drevnerusskoi literatury [Metropolitan Daniel - editor of "Dialectics". Proceedings of the Department of the Old Russian Literature]. V. XLI. L. 1988. pp. 357-363. (in Russian). 
15. Styazhkin N.I. Formirovanie matematicheskoi logiki [Formation of mathematical logic]. Moscow. 1967. 504 p. (in Russian).

16. Gnedenko B.V. Ocherki po istorii matematiki v Rossii [Essays on the history of mathematics in Russia]. Moscow-Leningrad. 1946. 247 p. (in Russian). 